\title{
The Effect of Competence on Employee Performance Mediated on Job Satisfaction (Case Study; Ministry of Finance PPSDM Employee)
}

\author{
Daniel Pangaribuan ${ }^{1}$, Pardomuan Robinson Sihombing ${ }^{2}$ \\ ${ }^{1}$ PPSDM-BPPK-Ministry of Finance \\ 2BPS-Statistics Indonesia, Jakarta \\ Email: dpangaribuan58@gmail.com, robinson@bps.go.id
}

\begin{abstract}
:
Research on competence and its effect on performance and job satisfaction is relatively rare. Included that is still rarely done is research on the effect of competence according to PerMenPANRB Number 38 of 2017 on performance and job satisfaction. This study also analyzes the effect of competence on ASN job satisfaction and places job satisfaction as a mediating variable of competence on ASN performance. Respondents in this study were PPSDM employees of the Ministry of Finance. The results showed that managerial competence had a direct and significant effect on work goals and performance of PPSDM employees. Work objectives have no direct and not significant positive effect on employee performance. In addition, activities do not mediate the effect on employee performance.
\end{abstract}

Keywords:

satisfaction; performance; competence; partial least square

\section{Introduction}

In general, research in the public sector focuses on performance and services. Competence factors and employee job satisfaction are increasingly important because the variables they influence are employee performance which is very important for employees and organizations. According to Sedarmayanti (2017), organizational performance is a combination of the performance of employees and management processes in the organization. Employee performance is the result of work which includes the quality and quantity achieved by an employee after carrying out the tasks that are his responsibility according to the assignments given by the organization. It is through this result or performance that a person or organization proves its accountability and becomes an object that is appreciated by stakeholders.

Research on competence and its effect on performance and job satisfaction is relatively rare. Included that is still rarely done is research on the influence of competence according to PerMenPANRB Number 38 (KemenpanRB, 2017) on performance and job satisfaction. Research in the commercial sector that has been carried out states that there is a positive and significant influence of competence and job satisfaction on employee performance. The importance of competency factors to improve employee performance has been investigated by Sotrisno and Gilang (2018). This study states that competence has a positive and significant effect on employee performance at PT. Telekomunikasi Indonesia Tbk Witel Bandung. Other research conducted by Ginanti, Muis, and Pono (2018), the results obtained by competence also have a positive and significant effect on performance through 


\section{Economit Journal: Scientific Journal of Accountancy, Management and Finance ISSN: 2775-5827 (Online), 2775-5819 (Print) \\ Vol. 1, No. 4, November 2021, Page: 203-211 \\ Email: economitjournal@gmail.com}

the mediating variable of job satisfaction, with indicators of knowledge, skills and attitudes for employee competence.

Recognizing the importance of the performance of these employees, the Government of Indonesia has made efforts to improve the performance of all State Civil Apparatuses (ASN). One of the efforts that have been made by the Government is to enact laws and regulations of the Minister of PANRB. In Law Number 5 of 2014 concerning ASN (KemenpanRB, 2014), regulated a merit system which is the basis for managing ASN. In the merit system, ASN policies and management are based on qualifications, competencies and performance. This merit system is the main factor used to provide employee incentives, including in determining the career progress of an employee.

It is also known that the competence of the State Civil Apparatus (ASN) has been regulated by the Regulation of the Minister for Empowerment of the State Civil Apparatus and Bureaucratic Reform (PerMenPANRB) Number 38 of 2017. This competence is relatively different from the competence of employees in general. This study uses competency standards according to the Regulation of the Minister of Administrative Reform and Bureaucratic Reform (PerMenPANRB) Number 38 of 2017 as a measuring tool for employee competence. Previous research still uses general competency measures according to the literature. This study also analyzes the effect of competence on ASN job satisfaction and places job satisfaction as a mediating variable of competence on ASN performance.

\section{Research Methods}

This research method uses a survey method. According to Sugiyono (2013), survey research is quantitative research. In this study, the population was PPSDM Ministry of Finance employees totaling 98 people and the Magelang Leadership Training Agency employees totaling 28 people, bringing the total population to 126 people. Given the relatively small number of populations, the entire population will be the sample of the research object. The variables in this study consisted of three variables consisting of one dependent variable (performance), one independent variable (competence) and one intervening/mediation variable (satisfaction). The variables and their indicators and references can be seen in Table 1 .

Table1. Research Variables and Indicators

\begin{tabular}{|c|c|c|c|}
\hline Research variable & Indicator & Reference & Indicator \\
\hline \multirow{8}{*}{$\begin{array}{l}\text { Employee } \\
\text { Competence }\end{array}$} & 1. Integrity & \multirow{8}{*}{$\begin{array}{l}\text { PerMenPANRB } \\
\text { Number } 38 \text { of } 2017 \\
\text { (KemenpanRB, 2017) }\end{array}$} & \multirow{8}{*}{1 to 8} \\
\hline & 2. Cooperation & & \\
\hline & 3. Communication & & \\
\hline & 4. Results Orientation & & \\
\hline & 5. Public Service & & \\
\hline & 6. Development of self and others & & \\
\hline & 7. Managing Change & & \\
\hline & 8. Decision Making & & \\
\hline \multirow[b]{4}{*}{ Performance } & 9. Quantity & \multirow{4}{*}{$\begin{array}{l}\text { Decree of the Minister } \\
\text { of Finance of the } \\
\text { Republic of Indonesia } \\
\text { Number } \\
467 / \text { KMK.01/2014 of } \\
2014 \text { (Kemenkeu, } \\
2014 \text { ) }\end{array}$} & \multirow[b]{4}{*}{9 to 12} \\
\hline & 10. Quality & & \\
\hline & 11. Time & & \\
\hline & 12. Cost & & \\
\hline
\end{tabular}




\begin{tabular}{|c|c|c|c|}
\hline \multirow{8}{*}{ Job satisfaction } & 13. Compensation & \multirow{8}{*}{ Colquitt et al. (2015) } & \multirow{8}{*}{13 to 19} \\
\hline & 14. Promotion & & \\
\hline & 15 Supervision & & \\
\hline & 16. Coworkers & & \\
\hline & 17. The work itself & & \\
\hline & 17. Quality & & \\
\hline & 18. Time & & \\
\hline & 19. Cost & & \\
\hline
\end{tabular}

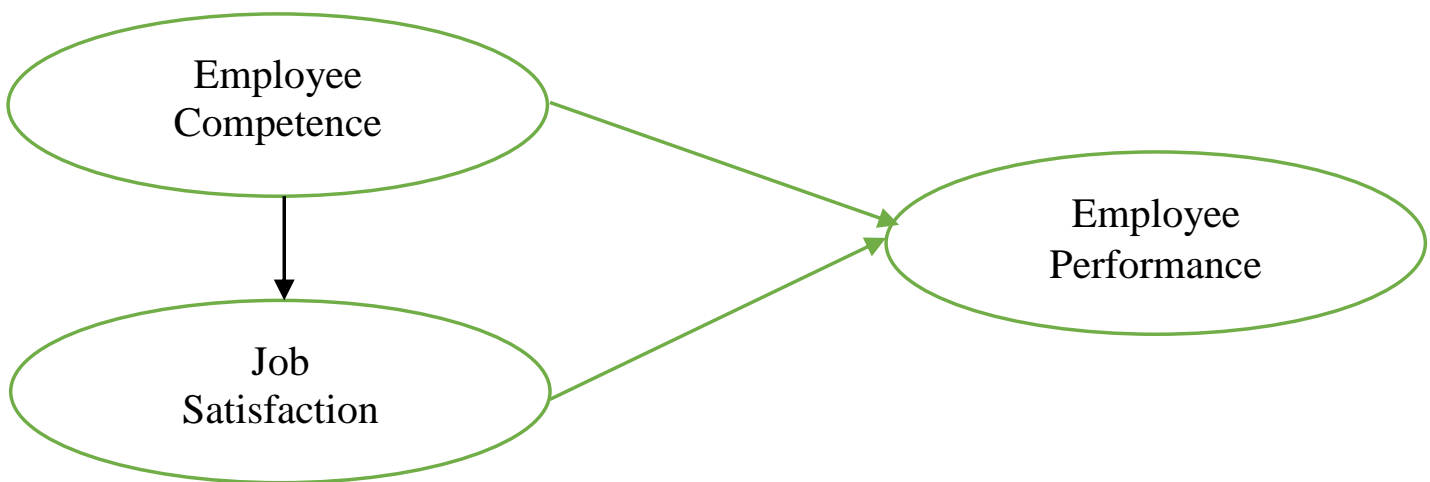

Figure 1. Conceptual Chart

This study uses measurements with Likert's scale. There are five options for each question. Number 1 is strongly disagree and number 5 is strongly agree. Data analysis in this study used Partial Least Square (PLS), which is a statistical test tool for variance-based structural equations. This data analysis technique according to Ghozali (2012) able to describe the latent variable (immeasurable directly), using indicators (manifest variable).

The tests carried out in SEM PLS consist of testing the outer model, testing the inner model and testing the hypothesis (Hair, Hult, Ringle, \& Sarstedt, 2014). The outer model test looks at the relationship between latent variables and their indicators, which are validity tests and reliability tests. The validity test used is the validity of the items indicated by the correlation or support for the total score. The validity test will use Confirmatory Factor Analysis, namely by using the Standardized Loading Factor Analysis (SLF) Indicator. An indicator is said to be valid if the loading factor $>0.7$. Other tests carried out are testing the outer model with indicators of convergent validity, discriminant validity and unidimensionality.

The reliability test is the consistency or stability of the score of a research instrument on the same individual, and is given at different times. Reliability testing using Cronbach Alpha and Composite Reability values. According to Now (Sekaran, 2010) reliability whose value is less than 0.60 is not good. While the value of 0.70 is acceptable, and values above 0.80 are good. Inner model testing can be done in three ways, namely R-Square, Q-Square and Goodness of Fit. The test method is Cronbach's Alpha with a limit of 0.60. Meanwhile, to test the hypothesis with PLS-SEM, it can be done by using the t-count value compared to the $\mathrm{t}$ table.

As mentioned in the conceptual framework, the model of this research model can be written as follows: 
Job Satisfaction $=\beta \_1$ Employee Performance+ $\varepsilon \_1$

Employee performance $=\gamma \_1$ Employee Performance $+\gamma \_2$ ob Satisfaction $+\varepsilon \_2$

Note: $\beta \_1, \gamma \_1$ and $\gamma_{-} 2$ are coeffient regression and $\varepsilon_{-} 1, \varepsilon \_2$ are term of error in model

The htpothesis in this research are:

- Employee competence has a positive effect on job satisfaction

- Employee competence has a positive effect on Employee Performance

- Job satisfaction has a positive effect on Employee Performance

- Job satisfaction mediates the indirect relationship between Employee competence and Employee performance

\section{Discussion}

Respondents in this study were all employees of the Human Resources Development Center (PPSDM) and employees of BDP Magelang. The total number of employees who became respondents was approximately 125 people. The questionnaire was submitted using a Google form. The number of respondents who have filled in is 93 people or $74.40 \%$. A description of the respondents who filled out the questionnaire is presented in Table 2.

Table 1. Demographic Characteristics of Respondents

\begin{tabular}{|c|l|r|r|}
\hline \multicolumn{2}{|c|}{ Demographics } & Frequency & Percentage \\
\hline \multirow{3}{*}{ Gender } & man & 53 & 57.0 \\
\cline { 2 - 4 } & Woman & 40 & 43.0 \\
\hline \multirow{4}{*}{ Age } & $20-30$ & 11 & 11.8 \\
\cline { 2 - 4 } & $31-40$ & 50 & 53.8 \\
\cline { 2 - 4 } & $41-50$ & 17 & 18.3 \\
\cline { 2 - 4 } & $51-60$ & 15 & 16.1 \\
\hline \multirow{3}{*}{ Position } & Functional & 21 & 22.6 \\
\cline { 2 - 4 } & Executor & 54 & 58.1 \\
\cline { 2 - 4 } & Structural & 18 & 19.4 \\
\hline \multirow{3}{*}{ group } & Group II & 69 & 74.2 \\
\cline { 2 - 4 } & Group IV & 24 & 25.8 \\
\hline
\end{tabular}

The descriptive results of respondents' answers are shown in Table 3. The results show that the minimum answer for competence is 2 , maximum 5 . The average value of the answers is 4.562 . The minimum value of respondents' answers for job satisfaction is 1 , the maximum is 5 , and the average answer value is 4,375 . The minimum value of respondents' answers for performance is 2 , the maximum is 5 , and the average answer value is 4,289. When compared to the variation in answers between variables, the most varied answers were on job satisfaction with a standard deviation of 0.741 , followed by variations in answers on performance.

Table 2. Descriptive Respondents' Answers

\begin{tabular}{|r|c|c|c|}
\hline & Competence & Satisfaction & Performance \\
\hline Min & 2 & 1 & 2 \\
\hline Max & 5 & 5 & 5 \\
\hline Mode & 5 & 5 & 4 \\
\hline mean & 4.56 & 4.37 & 4.28 \\
\hline std & 0.57 & 0.74 & 0.70 \\
\hline
\end{tabular}




\subsection{Testing the Measurement Model (Outer Model)}

Based on the outer loading test, there are several indicators whose outer values are below 0.7 . Indicators that score below 0.7 are then excluded from the model. Furthermore, indicators whose values are above 0.7 are reprocessed. The final result shows that all outer loading has been above 0.7 which is shown in Figure 2 .

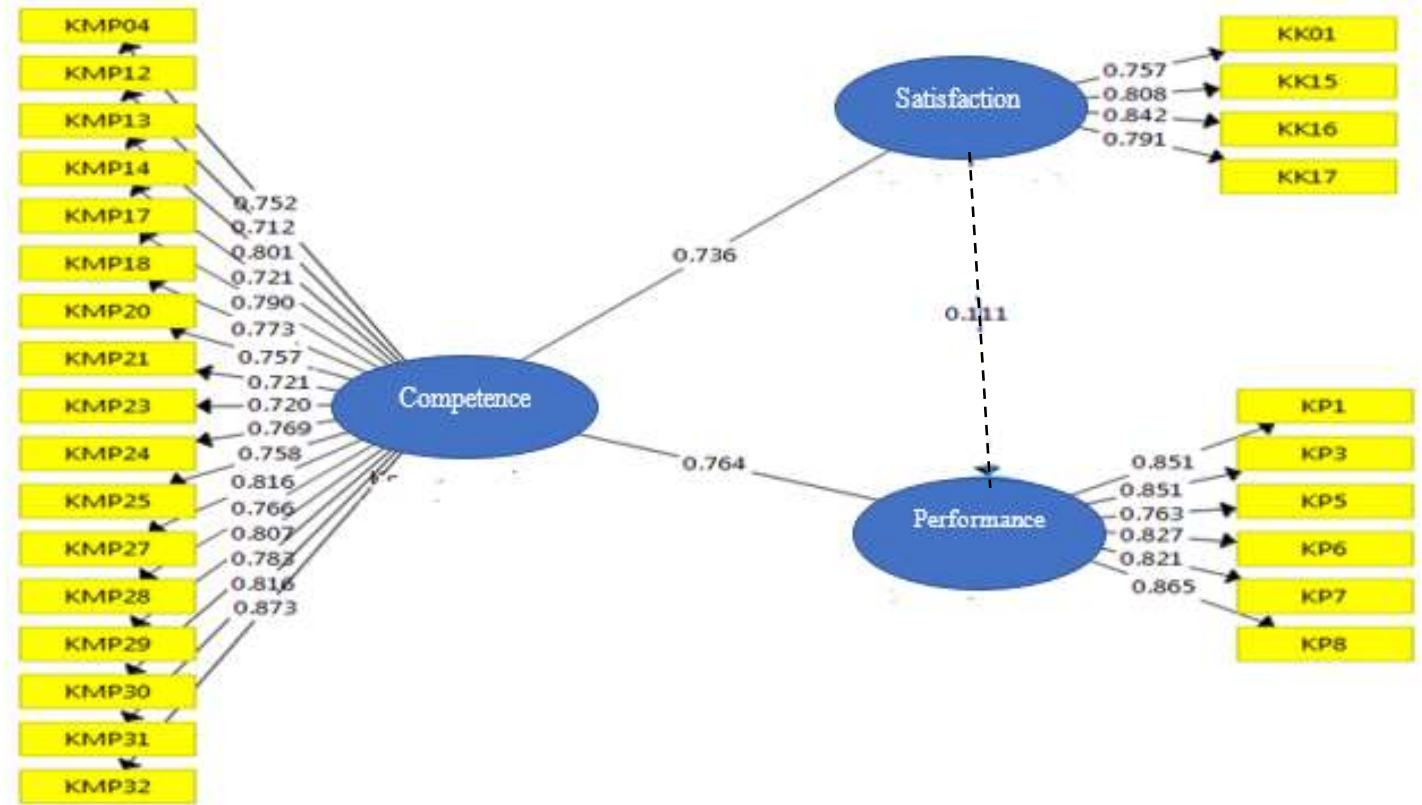

Figure 1. Outer Loading Test

Another way to assess validity apart from outer loading is to look at the average variance extracted (AVE) value for each construct. . It is recommended that the AVE value should be greater than 0.50 . The results of the AVE value for each construct can be seen in Table 4. The results show that the AVE value is already above 0.5. This means that all latent variables used in this study are valid because they have met the recommended AVE value $(>0.5)$.

Table 3. Average Variance Extracted (AVE)

\begin{tabular}{|l|r|}
\hline Variable & Average Variance Extracted (AVE) \\
\hline Job satisfaction & 0.640 \\
\hline Employee performance & 0.689 \\
\hline Employee competence & 0.599 \\
\hline
\end{tabular}

To test the reliability of the constructs, measurements were made with Composite Reliability and Cronbach's Alpha from the indicator blocks that measure the constructs. Table 5 shows the results of testing Composite Reliability and Cronbach's Alpha from Smart PLS. The SmartPLS output results in Table IV.5 show that all constructs already have Composite Reliability values above 0.70 and Cronbach's Alpha above 0.70 . So it can be concluded that the construct has good reliability.

Table 4. Composite Reliability and Cronbach Alpha

\begin{tabular}{|c|c|c|}
\hline Variable & $\begin{array}{c}\text { Cronbach's } \\
\text { Alpha }\end{array}$ & $\begin{array}{c}\text { Composite } \\
\text { Reliability }\end{array}$ \\
\hline Job satisfaction & 0.812 & 0.876 \\
\hline
\end{tabular}




\begin{tabular}{|c|c|c|}
\hline Employee Performance & 0.910 & 0.930 \\
\hline Employee competence & 0.958 & 0.962 \\
\hline
\end{tabular}

Source: SmartPLS 3.28 . output

\subsection{Structural Model Testing (Inner Model)}

Structural model testing is done byusing $\mathrm{R}$-square for the dependent variable and assessing the path coefficient for the independent variable. Furthermore, the Stone-Geisser Qsquare test was carried out to measure predictive relevance and continued to assess goodness of fit (gof).

Table 6 shows the value of the coefficient of determination/adjusted $\mathrm{R}$ square. The adjusted $\mathrm{R}$ Square value of 0.536 means that the independent variable (competence) is able to explain the mediating variable (job satisfaction) by 53.6 percent. The rest is explained by other variables outside the model. While the adjusted $R$ Square value of 0.715 means that the independent variable (competence) and the mediating variable (job satisfaction) are able to explain the dependent variable of 71.5 percent. The rest is explained by other variables outside the model.

Table 5. Adjusted R Square Value

\begin{tabular}{|c|c|c|}
\hline Variable & R Square & R Square Adjusted \\
\hline Job satisfaction & 0.541 & 0.536 \\
\hline Employee Performance & 0.721 & 0.715 \\
\hline
\end{tabular}

In Table 7 displays the value of Q-square. The Q-square value of 0.313 for model 1 and 0.42 indicates the model is fit because the lower limit of the Q-square value is 0.3.

Table 6. Q Square Value

\begin{tabular}{|c|c|c|c|}
\hline Variable & SSO & SSE & Q2=1-SSE/SSO \\
\hline Job satisfaction & 372 & 255.619 & 0.313 \\
\hline Employee Performance & 558 & 305.845 & 0.452 \\
\hline
\end{tabular}

Furthermore, the evaluation of the Goodness of Fit value of this model was carried out using R2 the dependent latent variable with the same interpretation as the regression. A model is said to be good if the gof value is above 0.38. From the calculation results $G o F=\sqrt{\overline{A V E} * \overline{R^{2}}}=\sqrt{0,643 * 0.631}=\sqrt{0,4054}=0.6367$. So it can be said that the hypothesized model is appropriate because the value ofthe gof is above 0.38 which means the model is good.

Table 7. Direct Effect of Independent Variables on Dependent Variables

\begin{tabular}{|c|c|c|c|c|c|}
\hline Connection & Coefficient & $\begin{array}{c}\mathrm{T} \\
\text { Statistics }\end{array}$ & PValues & Decisionn & Conclusion \\
\hline $\begin{array}{c}\text { Job Satisfaction -> } \\
\text { Employee Performance }\end{array}$ & 0.111 & 1.029 & 0.152 & Reject H1 & No effect \\
\hline $\begin{array}{c}\text { Employee competence - } \\
\text { > Job Satisfaction }\end{array}$ & 0.736 & 10,758 & 0.000 & $\begin{array}{c}\text { Accept } \\
\text { H1 }\end{array}$ & $\begin{array}{c}\text { Take } \\
\text { effect }\end{array}$ \\
\hline $\begin{array}{c}\text { Employee } \\
\text { competence } \\
\text { Employee } \\
\text { Performance }\end{array}$ & 0.764 & 7.514 & 0.000 & $\begin{array}{c}\text { Accept } \\
\text { H1 }\end{array}$ & $\begin{array}{c}\text { Take } \\
\text { effect }\end{array}$ \\
\hline
\end{tabular}




\section{Table 8 interpretation:}

a. Employee competence has a direct and significant positive effect on job satisfaction with a coefficient of 0.736 , $\mathrm{t}$ stat $=10,758>\mathrm{t}$ table $=1.64$ and prob value $=0.000<$ alpha $=$ 0.05 . This means that an increase of 1 competency point will increase job satisfaction by 0.736 points assuming other variables are constant.

The results of this study are in line with the results of research conducted by Kartika and Sugiarto (2016) which concludes that employee competence has a positive and significant effect on employee performance.

b. Employee competence has a direct and significant positive effect on employee performance with a coefficient of 0.764 , the value of $\mathrm{t}$ stat $=7.514>\mathrm{t}$ table $=1.64$ and the value of prob. value $=0.000<$ alpa $=0.05$. This means that a 1 point increase in competence will increase performance by 0.764 points assuming other variables are constant.

The results of this study are in line with the results of research conducted by Ginanti, Muis, \& Pono (2018)who said that competence, training, and compensation had an effect on employee job satisfaction. The results of this study are also in line with the results of research conducted by Pranazhira and Sukmawati (2017) who said that Competence and compensation affect job satisfaction and employee is.

The competence of PPSDM employees that we mean in this study is the managerial competence of ASN in accordance with Permenpan RB number 38 of 2017. The managerial competence of ASN according to this regulation consists of 8 elements, namely Integrity, Cooperation, communication, result orientation, public service, self and people development others, managing change and making decisions.

c. Job satisfaction has no direct and not significant positive effect on employee performance with a coefficient of $0.111, \mathrm{t}$ stat $=1.029<\mathrm{t}$ table $=1.64$ and prob value $=$ $0.152>$ alpha $=0.05$. This means that there is not enough evidence that an increase of 1 point in job satisfaction will increase performance by 0.111 points assuming other variables are constant.

Pangaribuan and Sihombing research results (2021) with the title Analysis of employee job satisfaction with gap analysis and quadrant map on PPSDM employees concluded that the job satisfaction of PPSDM employees was in the less satisfied category. The promotion factor and the job itself contributed to the dissatisfaction of PPSDM employees. One of the objectives of this study is to continue previous research by analyzing the effect of job satisfaction on employee performance in bureaucratic organizations.

Table 8. Indirect Effect of Competence on Performance

\begin{tabular}{|l|c|c|c|c|c|}
\hline Connection & Coefficient & T Statistics & PValueice & Decision & Conclusion \\
\hline Employee competence - & 0.082 & 1.017 & 0.155 & reject H1 & $\begin{array}{c}\text { No } \\
\text { take effect }\end{array}$ \\
\hline $\begin{array}{l}\text { Iob Satisfaction -> } \\
\text { Employee Performance }\end{array}$ & & & & & \\
\hline
\end{tabular}

On Table 9 shows an indirect relationship between employee competence through job satisfaction and employee performance. Job satisfaction does not mediate the effect of competence on employee performance. This can be seen from the coefficient of 0.082 , $t$ stat $=1.017<\mathrm{t}$ table $=1.64$ and the value of prob. value $=0.155>$ alpha $=0.05$. This means that there is not enough evidence of an increase in job satisfaction to mediate the effect of competence on employee performance. 


\section{Conclusions}

Managerial competence is an important factor in encouraging the performance of PPSDM employees. We can see its effect on Job Satisfaction and Employee Performance, in the discussion section of the results above. This managerial competence has a direct and significant positive effect on employee performance. The managerial competence of PPSDM employees has a significant positive effect on employee performance in increasing the quantity of training, increasing the quality of training, shorter training time and more effective training costs.

From the results of the t-test in the discussion above, managerial competence has a direct and significant positive effect on PPSDM employee job satisfaction. The elements of competence that have the most influence on performance and job satisfaction are decision making, managing change, and result orientation.

Job Satisfaction has no direct and not significant positive effect on employee performance. Satisfaction. Employee job satisfaction has not been optimal on the indicators of promotion and the role of supervision.

Job satisfaction does not mediate the effect of competence on employee performance. The factor that influences this condition is because the job satisfaction variable has no direct and not significant positive effect on employee performance. PPSM employee job satisfaction has not been able to be a good mediation for managerial competence to influence employee performance. There are differences in the results of measuring the performance of PPSDM employees according to Performance Achievements and Real Performance Results with the results according to research surveys. This difference is caused, among other things, because Performance Achievements and Performance Results have not included the element of cost effectiveness in evaluating the performance of individual employees.

\subsection{Limitations and Future Plan}

PPSDM in order to continue to improve the managerial competence of employees, among others, through training, because it is an important factor in improving employee performance and job satisfaction. In addition, PPSDM should continue to improve employee job satisfaction on promotion indicators and the role of supervision is not optimal.

Measuring Employee Performance Achievements to include elements of cost effectiveness as a measured factor. In connection with this study, job satisfaction does not have a significant positive effect on employee performance, it is recommended that further research be conducted to explore the effect of employee job satisfaction on employee performance in government agencies.

\section{References}

Colquitt, LePine, \& Wesson. (2015). Organizational Behavior. 4th Edition. China: McGrawHill.

Ghozali. (2012). Structural Equation Modeling Metode Alternatif dengan Partial Least Square (PLS). Semarang: Badan Penerbit-Undip.

Ginanti, M. G., Muis, M., \& Pono, M. (2018). Pengaruh Kompetensi, Pelatihan dan Kompensasi Terhadap Kinerja dengan Kepuasan Kerja Sebagai Variabel Mediasi Pada 
Tim Tanggap Darurat Fire and Emergency Services Wilayah Kerja Tambang PT. Vale Ind. Tbk. Hasanuddin Journal of Applied Business and Entrepreneurship, 1(4), 65-72.

Hair, J. F., Hult, G. M., Ringle, C. M., \& Sarstedt, M. (2014). A Primer on Partial Least Squares Structural Equation Modeling (PLS-SEM). Los Angeles: SAGE Publication Inc.

Kartika, L. N., \& Sugiarto, A. (2016). Pengaruh Tingkat Kompetensi Terhadap Kinerja Pegawai Administrasi Perkantoran. Jurnal Ekonomi Dan Bisnis, 17(1), 73-90.

Kemenkeu. (2014). Keputusan Menteri Keuangan Nomor 467/KMK.01/2014 Tentang Pengelolaan Kinerja di lingkungan Kementerian keuangan. Jakarta: Kemenkeu.

KemenpanRB. (2014). Undang-Undang Nomor 5 Tentang Aparatur Sipil Negara. Jakarta: KemenpanRB.

KemenpanRB. (2017). Peraturan Menteri Pendayagunaan Aparatur Negara dan Reformasi Birokrasi Tentang Standar Kompetensi Jabatan Aparatur sipil Negara Nomor 38. Jakarta.

Pangaribuan, D., \& Sihombing, P. R. (2021). Analisis Kepuasan Kerja Pegawaidengan Analisis GapdanKuadranPadaPegawai PPSDM-BPPK-Kemenkeu. Perspektif: JurnalEkonomi\&ManajemenUniversitasBinaSaranaInformatika, 19(2), 131-137.

Pranazhira, G. R., \& Sukmawati, A. (2017). Pengaruh Kompetensi dan Kompensasi terhadap Kepuasan Kerja dan Work Engagement Karyawan UKM Susu Kambing Kabupaten Bogor. Jurnal Manajemen dan Organisasi, 8(1), 60-74.

Sedarmayanti. (2017). Perencanaan dan Pengembangan Sumber Daya Manusia. Bandung: PT. Refika Aditama.

Sekaran, B. (2010). Reseach Methods for Business. United Kingdom: John Wiley \& Sons.

Soetrisno, A. P., \& Gilang, A. (2018). Pengaruh Kompetensi Terhadap Kinerja Karyawan (Studi di PT. Telekomunikasi Indonesia Tbk Witel Bandung). Jurnal Riset Bisnis dan Manajemen, 8(1), 62-75.

Sugiyono. (2013). Metode Penelitian Manajemen. Yogyakarta: AlFABETA. 